\title{
MUDHARABAH PADA BAITUL MAL WAT TAMWIL SIDOGIRI CABANG PEMBANTU WARU SIDOARJO
}

\author{
Shania Putri Ayu A \\ UIN Sunan Ampel, Surabaya \\ shaniaputriayu99@gmail.com
}

Via Ratnasari

UIN Sunan Ampel, Surabaya

viaratnasari.vr@gmail.com

Dewi Audrynita B.B.

UIN Sunan Ampel, Surabaya

dewiaudrynita14@gmail.com

\section{Affrido Galuh Mulyono UIN Sunan Ampel, Surabaya affridogm46@gmail.com}

\begin{abstract}
The Sidogiri Integrated Joint Business BMT Cooperative, abbreviated as "Koperasi BMT UGT Sidogiri" began operating on 5 Rabiul Awal $1421 \mathrm{H}$ or 6 June $2000 \mathrm{AD}$ in Surabaya and then obtained a Cooperative Legal entity from the Regional Office of the PK and M Cooperative Office of East Java Province with a decree Number: 09 / BH / KWK.13 / VII / 2000 dated 22 July 2000. There are two products at BMT UGT Sidogiri Waru, namely: financing products and savings products. The mudharabah agreement at BMT Sidogiri is used for savings products consisting of general sharia savings, al-haromain savings, umrah al-hasanah savings, Eid al-Fitr savings, qurban savings, savings from student care institutions, term mudharabah savings, and term mudharabah savings. Based on the analysis of Islamic law, the practice of mudharabah at BMT Sidogiri has fulfilled the pillars and requirements of mudharabah. Customers as shahibul mal and BMT as mudharib, capital, and ratio are also explained in detail in each product, the consent of the qabul is contained in the contract and BMT Sidogiri has the authority to manage customer funds.
\end{abstract}

Keywords: Mudharabah, BMT Sidogiri, Islamic Law

Abstrak: Koperasi BMT Usaha Gabungan Terpadu Sidogiri disingkat "Koperasi BMT UGT Sidogiri" mulai beroperasi pada tanggal 5 Rabiul Awal $1421 \mathrm{H}$ atau 6 Juni 2000 M. di Surabaya dan kemudian mendapatkan badan Hukum Koperasi dari Kanwil Dinas Koperasi PK dan M Propinsi Jawa Timur dengan SK Nomor: 09/BH/KWK.13/VII/2000 tertanggal 22 Juli 2000. Produk di BMT UGT Sidogiri Waru ada dua yaitu: produk pembiayaan dan produk simpanan. Akad mudharabah

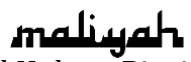


di BMT Sidogiri digunakan pada produk simpanan yang terdiri dari tabungan umum syariah, tabungan haji al-haromain, tabungan umrah al-hasanah, tabungan idul fitri, tabungan qurban, tabungan lembaga peduli siswa, tabungan mudharabah berjangka, dan tabungan mudharabah berjangka plus. Berdasarkan analisis hukum Islam praktik mudharabah di BMT Sidogiri telah memenuhi rukun dan syarat mudharabah. Nasabah sebagai shahibul mal dan BMT sebagai mudharib, modal dan nisbah juga dijelaskan secara rinci di setiap produk, ijab qabul tertuang dalam akad dan BMT Sidogiri memiliki kewenangan mengelola dana nasabah.

Kata Kunci: Mudharabah, BMT Sidogiri, Hukum Islam.

\section{Pendahuluan}

Pada dasarnya aktifitas manusia baik dalam duniawi maupun ukhrawi tidak lepas dari tujuan apa yang akan ia peroleh selepas aktifitas tersebut dengan berbagai macam perbedaan sudut pandang manusia itu sendiri. ${ }^{1}$ Maka tidak jarang diantara kita yang acap kali menemukan ayat dalam kitab suci al-Qur'an yang mendorong perdagangan dan perniagaan, dan Islam sangat jelas sekali menyatakan sikap bahwa tidak boleh ada hambatan dalam perdagangan dan bisnis yang jujur dan halal, agar setiap orang memperoleh penghasilan untuk menafkahi keluarga dan memberikan sedekah kepada mereka yang kurang beruntung. ${ }^{2}$ Melihat pada bahasan singkat di atas maka penulis akan membahas tentang konsep transaksi mudharabah. Mudharabah adalah bentuk kerja sama antara dua pihak atau lebih, di mana pemilik modal mempercayakan sejumlah modal kepada pengelola dengan suatu perjanjian di awal. ${ }^{3}$

Lembaga keuangan syariah adalah lembaga keuangan yang memiliki nilai-nilai Islam di dalamnya. ${ }^{4}$ Nilai-nilai

\footnotetext{
${ }^{1}$ Firdaweri, "Perikatan Syariah Berbasis Mudharabah (Teori Dan Praktik)," $A S A S$ 6, no. 2 (2014): 54-77.

${ }^{2}$ Ahmad Musadad, “Perniagaan Dalam Al-Qur'an (Studi Perbandingan Tafsir Ahkamul Quran Karya Ibnu Al-Arabi Dan Tafsir Ahkamul Quran Karya AlKiya Al-Harasi)," Et-Tijarie 3, no. 2 (2016): 51-73.

${ }^{3}$ Mahmudatus Sa'diyah and Meuthiya Athifa Arifin, "Mudharabah Dalam Fiqih Dan Perbankan Syari'Ah,” Equilibrium : Jurnal Ekonomi Syariah 1, no.

Desember (2013): 302-23.

${ }^{4}$ Budi Kolistiawan, "Tantangan Lembaga Keuangan Syariah Dalam Menghadapi Masyarakat Ekonomi ASEAN," MUQTASID Jurnal Ekonomi Dan
} 
perbankan syariah tersebut dilandaskan pada sumber hukum Islam, yaitu al-Qur'an dan hadis. ${ }^{5}$ Perkembangan lembaga keuangan syariah di Indonesia sudah tersebar luas. ${ }^{6}$ Pada dasarnya lembaga keuangan syariah ini membantu umat Islam agar terhindar dengan riba yang diharamkan dalam Islam, ${ }^{7}$ maka dari itu cukup banyak umat Islam di Indonesia yang mulai menggunakan layanan lembaga keuangan syariah baik itu yang berupa bank maupun non bank.

Lembaga keuangan syariah di Indonesia sudah tersebar luas, mulai dari bank syariah, koperasi syariah, reksadana syariah, pasar modal syariah, pegadaian syariah, dan lain sebagainya. Pada lembaga keuangan syariah ini semua akad yang digunakan sesuai dengan prinsip ekonomi syariah yang bersifat saling menguntungkan.

BMT merupakan bagian dari lembaga keuangan syariah yang ada di Indonesia. ${ }^{8}$ Di antara produk yang ditawarkan BMT adalah mudharabah, maka dalam makalah ini penulis menganalisis praktik mudharabah di BMT Sidogiri Cabang Pembantu Waru Sidoarjo Jawa Timur.

\section{Pengertian Mudharabah}

Mudharabah berasal dari kata dharab, berarti memukul atau berjalan. Pengertian memukul atau berjalan ini lebih

Perbankan Syariah 8, no. 1 (2017): 54-64, https://doi.org/10.18326/muqtasid.v8i1.78-94.

${ }^{5}$ Adzan Noor Bakri and Umi Masruroh, "Penerapan Nilai-Nilai Islam Dalam Bank Berbasis Syariah Dan Pengaruh Terhadap Loyalitas Nasabah,” DINAMIS - Journal of Islamic Management And Bussines 1, no. 1 (2018): 33-45.

${ }^{6}$ Agus Marimin and Abdul Haris Romdhoni, "Perkembangan Bank Syariah Di Indonesia," Jurnal Ilmiah Ekonomi Islam 1, no. 02 (2017): 75-87, https://doi.org/10.29040/jiei.v1i02.30.

7 Ahmad Atabik, “Analisis Historis Perkembangan," Iqtishadia 6, no. 2 (2013): 357-78.

${ }^{8}$ Novita Dewi Masyithoh, “Analisis Normatif Undang-Undang No. 1 Tahun 2013 Tentang Lembaga Keuangan Mikro (Lkm) Atas Status Badan Hukum Dan Pengawasan Baitul Maal Wat Tamwil (Bmt)," Economica: Jurnal Ekonomi Islam 5, no. 2 (2014): 17-36, https://doi.org/10.21580/economica.2014.5.2.768. 
tepatnya adalah proses seseorang memukulkan kakinya dalam menjalankan usahanya. ${ }^{9}$

Menurut Fatwa Dewan Syariah Nasional (DSN-MUI) Mudharabah merupakan kerjasama antara pihak pertama (shahibul mal) dengan pihak kedua (mudharib), dimana dana $100 \%$ dari pihak shahibul mal dan keuntungan usaha mudharabah dibagi menurut akad perjanjian, sedangkan apabila rugi ditanggung oleh pemilik modal selama kerugian itu tidak disebabkan oleh kelalaian si pengelola. ${ }^{10}$

Menurut Adiwarman A Karim pembiayaan mudharabah adalah bentuk kontrak antara dua pihak dimana satu pihak berperan sebagai pemilik modal dan mempercayakan sejumlah modalnya untuk dikelola oleh pihak kedua, yakni si pelaku usaha, dengan tujuan untuk mendapatkan uang.

Berbeda dengan pendapat Dinas Koperasi Jawa Timur, pengertian mudharabah adalah akad antara pihak pemilik modal (shahibul mal) dengan pengelola (mudharib) untuk memperoleh pendapatan atau keuntungan.

Dari pengertian-pengertian diatas dapat disimpulkan bahwa pembiayaan mudharabah didanai sepenuhnya oleh penyandang dana (shahibul mal) dan pengelola usaha (mudharib) tinggal menjalankan usaha tanpa penanaman dana sasuai dengan kesepakatan dan keuntungan dibagi berdasarkan nisbah yang telah disepakati di awal akad. ${ }^{11}$

\section{Rukun dan Syarat Mudharabah}

Akad mudharabah harus memenuhi persyaratan berikut ini:

\footnotetext{
${ }^{9}$ Karlina Aprilianingrum Bawenti and Faradila Hasan, "Mudharabah Bank Syariah Ditinjau Dari Undang-Undang Nomor 21 Tahun 2008 Tentang Perbankan Syariah," Jurnal Ilmiah Al-Syir'ah 16, no. 1 (2018): 35-57, https://doi.org/10.30984/jis.v16i1.646.

${ }^{10}$ DSN MUI, "FATWA DEWAN SYARI'AH NASIONAL NO: 07/DSNMUI/IV/2000 Tentang PEMBIAYAAN MUDHARABAH (QIRADH)" (Jakarta, 2000).

${ }^{11}$ Muhammad Yazid, Fiqh Muamalah Ekonomi Islam (Surabaya: Imtiyaz, 2017), 151-153.
} 
1. Masing-masing pihak memenuhi persyaratan kecakapan wakalah.

2. Modal (ra's al-mal) harus jelas jumlahnya. Bukan berupa barang dagang, artinya harus berupa harga tukar (tsaman) dan penyerahan harus tunai seluruhnya kepada pengusaha. Sebelum adanya pembagian keuntungan milik bersama, presentase keuntungan dan waktu pembagian harus disepakati bersama dan dinyatakan dengan jelas.

3. Modal yang sudah diserahkan oleh pemodal akan dikelola pengusaha dan mempunyai hak tanpa campur dari pihak pemodal.

Akad mudharabah akan terlaksana apabila memenuhi rukun berikut ini:

1. Pelaku (pemilik modal maupun pelaksana usaha)

Pada dasarnya rukun dari akad mudharabah sama dengan rukun jual beli, dan ditambah satu faktor yaitu nisbah keuntungan. Transaksi dalam akan mudharabah melibatkan dua pihak. Pihak pertama sebagai pemilik modal (shahibul mal) dan pihak kedua sebagai pengelola usaha (mudharib atau amil). Jadi, tanpa dua pihak ini tidak akan terlaksana akad mudharabah.

2. Obyek mudharabah (modal dan kerja).

Faktor selanjutnya adalah konsekuensi logis dari tindakan yang dilakukan pelaku. Pihak shahibul mal menyerahkan modal sebagai obyek mudharabah dan keahlian (kerja) diserahkan oleh pelaksana usaha sebagai obyek mudharabah.

3. Persetujuan kedua belah pihak (ijab-qabul).

Persetujuan dari kedua pihak adalah konsekuensi prinsip sama sama rela (an tarodin minkum). Artinya, kedua pihak harus sepakat untuk sama sama mengikatkan diri dalam akan mudharabah. Si pemilik modal setuju sebagai tugasnya untuk menyediakan dana, dandisisi lain pelaksana usaha setuju dengan tanggung jawabnya menyerahkan keahlian kerjanya.

4. Nisbah keuntungan

Faktor berikutnya adalah nisbah. Nisbah adalah rukun yang 
tidak ada dalam akad jual beli, menjadi cirri khas pada mudharabah. Nisbah mencerminkan imbalan yang berhak diterima oleh pihak yang terkait dalam akad mudharabah. Imbalan untuk pemodal atas penyertaan modal, dan imbalan kepada mudharib atas kontribusi kerjanya. Dengan nisbah atau pembagian keuntungan inilah yang dikatakan bisa mencegah terjadinya perselisihan diantara mereka. ${ }^{12}$

\section{Macam-Macam Mudharabah}

1. Mudharabah Mutlaqah

Yang dimaksud dengan transaksi ini adalah bentuk kerjasama antara shahibul mal dan mudharib (pengusaha/nasabah) yang cakupannya sangat luas dan tidak dibatasi oleh spesifikasi jenis usaha, waktu, dan daerah bisnis. ${ }^{13}$

Teknik mudharabah mutlaqah dalam bank adalah kerjasama antara bank dengan mudharib atau dalam hal ini nasabah yang bisa mengelola suatu usaha yang produktif dan halal atau yang mempunyai keahlian atau keterampilan lainnya. Hasil atau keuntungan yang didapatkan dari penggunaan dana dibagi berdasarkan nisbah yang telah disepakati. Contoh produk mudharabah mutlaqah adalah Tabungan Mudharabah dan Depostio Mudharabah.

2. Mudharabah Muqayyadah

Mudharabah muqayyadah atau disebut juga dengan istilah restriceted mudharabah/specified mudharabah adalah kebalikan dari mudharabah mutlaqah. Si mudharib dibatasi dengan batasan jenis usaha, waktu, atau tempat usaha. Artinya tidak semua usaha bisa dijalankan dengan modal tersebut, jadi hanya usaha yang telah ditentukan (perjanjian) yang boleh dikelola.

Teknis mudharabah muqayyah dalam bank adalah akad

12 Adiwarman Karim, Bank Islam: Analisis Fiqih Dan Keuangan (Jakarta: PT Raja Grafindo Persada, 2004), 182.

${ }^{13}$ Muhammad Syafii Antonio, Bank Syariah (Jakarta: Gemma Insani, 2001), 97. 
kerjasama antara shahibul mal dengan bank. Modal yang diterima dari shahibul mal dikelola bank untuk diinvestasikan ke dalam proyek yang ditentukan oleh pemilik modal terkait. Hasil keuntungan yang diperoleh dibagi sesuai nisbah yang telah disepakati bersama.

Contoh produk Mudharabah Muqayyadah:

a. Mudharabah Muqayyadah On Balance Sheet (investasi terikat) adalah pengelolaan dana yang mempunyai syarat sehingga mudharib hanya melakukan mudharabah di bidang tertentu, waktu, cara dan tempat tertentu saja. Jenis mudharabah ini merupakan simpanan khusus (restricted investment) yaitu pemilik dana menentukan syarat yang harus dipatuhi oleh pihak bank. Contohnya, disyaratkan untuk bisnis tertentu atau nasabah tertentu.

b. Mudharabah Muqayyadah of Balance Sheet adalah jenis mudharabah yang penyerahan dana mudharabah langsung kepada pelaksana usahanya. Bank bertugas sebagai perantara yang mempertemukan antara pemilik dana dengan pelaksana usaha.

\section{Ketentuan Mudharabah}

Terdapat beberapa ketentuan dalam mudharabah, yaitu:

1. Pelaku

a. Pelaku harus cakap hukum dan baligh.

b. Pelaku akad mudharabah dapat dilakukan sesama muslim atau non muslim.

c. Pemilik dana tidak boleh ikut campur dalam pengelolaan usaha tetapi ia boleh mengawasi.

\section{Modal}

a. Modal yang diserahkan dapat berbentuk uang dan asset lainnya, harus jelas jumlah dan jenisnya.

b. Modal harus tunai dan tidak utang. Tanpa adanya setoran modal, berarti pemilik tidak memberikan kontribusi apapun padahal pengelola harus bekerja.

c. Modal harus diketahui dengan jelas jumlahnya sehingga dapat dibedakan dari keuntungan.

d. Pada akad mudharabah mutlaqah, mudharib tidak 
diperbolehkan melakukan tindakan-tindakan yang keluar dari ketentuan syara'.

e. Pada akad mudhrabah muqayyadah, mudharib dalam pengelolaan modal tidak boleh menjalankan modal di luar usaha yang telah ditentukan bersama dengan pemilik modal

3. Mudharib boleh melaksanakan berbagai macam usaha sesuai dengan akad yang telah disepakati bersama antara bank syariah dan nasabah. Bank syariah tidak ikut serta dalam mengelola perusahaan, akan tetapi memiliki hak untuk melakukan pembinaan dan pengawasan terhadap mudharib. ${ }^{14}$

4. Jika usaha mengalami kerugian, maka seluruh kerugian ditanggung oleh pemilik dana, kecuali jika ditemukan adanya kelalaian atau kesalahan ditanggung oleh pengelola dana, seperti penyelewengan, kecurangan, dan penyalahgunaan dana.

5. Ijab qabul, adalah pernyataan dan ekspresi saling rida atau rela di antara pihak-pihak pelaku akad yang dilakukan secara verbal, tertulis, melalui korespondensi atau menggunakan cara-cara komunikasi modern.

6. Nisbah keuntungan

a. Prosentase, nisbah keuntungan harus dinyatakan dalam bentuk prosentase antara kedua belah pihak, bukan dinyatakan dalam nilai nominal Rp tertentu.

b. Bagi untung dan bagi hasil

Ketentuan diatas itu merupakan konsekuensi logis dari karakteristik akad mudharabah itu sendiri, yang tergolong ke dalam kontrak investasi. Dalam kontrak ini, return dan timing cash flow kita tergantung pada kinerja sektor rillnya. Bila laba bisnisnya besar, kedua belah pihak mendapat bagian yang besar pula. Bila laba bisnisnya kecil, mereka mendapat bagian yang kecil juga. Filosofi ini hanya dapat berjalan jika nisbah laba ditentukan dalam bentuk prosentase.

${ }^{14}$ Ismail, Perbankan Syariah (Jakarta: Kencana, 2011), 170. 
c. Jaminan

Untuk menghindari adanya moral hazard dari pihak mudharib yang lalai atau menyalahi kontrak ini, maka shahibul mal dibolehkan meminta jaminan tertentu kepada mudharib. Jadi tujuan pengenaan jaminan dalam akad mudharabah adalah untuk menghindari moral hazard mudharib, bukan untuk mengamankan nilai imvestasi yang timbul disebabkan karena faktor bisnis, jaminan mudharib tidak dapat disita oleh shahibul mal.

d. Menentukan besarnya nisbah. Besarnya nisbah ditentukan berdasarkan kesepakatan masing-masing pihak yang berkontrak. Jadi angka besaran nisbah ini muncul sebagai hasil tawar menawar antara shahibul mal dengan mudharib. Dengan demikian angka nisbah ini bervariasi. Namun para ahli fiqh sepakat bahwa nisbah 100:0 tidak diperbolehkan. ${ }^{15}$

e. Cara menyelesaikan kerugian

1) Diambil terlebih dahulu dari keuntungan, karena keuntungan merupakan pelindung modal.

2) Bila keuntungan melebihi keuntungan, baru diambil pokok modal.

7. Pembatalan mudharabah

a. Tidak terpenuhinya salah satu atau beberapa syarat mudharabah.

b. Pengelola dengan sengaja meninggalkan tugasnya sebagai pengelola modal atau pengelola modal berbuat sesuatu yang bertentangan dengan tujuan akad.

c. Apabila pelaksana atau pemilik modak meninggal dunia atau salah seorang pemilik modal meninggal dunia, mdharabah jadi batal. ${ }^{16}$

\section{Skema Mudharabah}

${ }^{15}$ Karim, Bank Islam: Analisis Fiqih Dan Keuangan, 204-208.

${ }^{16}$ Hendi Suhendi, Fiqh Muamalah (Jakarta: PT Raja Grafindo Persada, 2013), 143. 


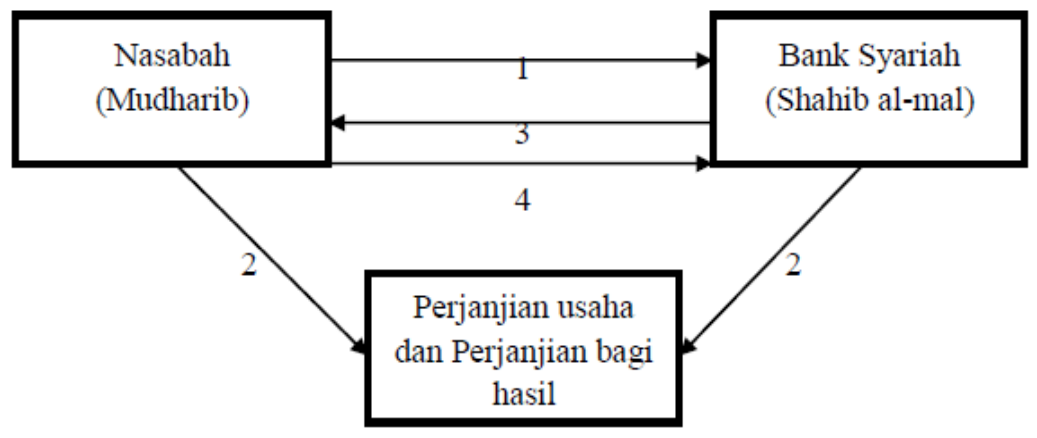

Ketentuan Skema:

1. Nasabah datang ke Bank Syariah dengan maksud untuk mengajukan pembiayaan mudharabah.

2. Kemudian nasabah dengan Bank Syariah melakukan sebuah perjanjian, yang meliputi usaha apa yang akan dijalankan oleh nasabah, dan juga ketika sudah ditentukan usaha yang akan di lakukan, maka kemudian melakukan sistem bagi hasil di antara kedua belah pihak sesuai dengan ketentuan akad.

3. Setelah selesai melakukan kesepakatan dalam akad, kemudian bank selaku shahib al- mal memberikan modal kepada nasabah.

4. Pengembalian pokok hutang dan nisbah yang dilakukan oleh nasabah secara bertahap dan sesuai kesepakatan.

\section{Profil BMT UGT Sidogiri}

Koperasi BMT Usaha Gabungan Terpadu Sidogiri disingkat "Koperasi BMT UGT Sidogiri" mulai beroperasi pada tanggal 5 Rabiul Awal $1421 \mathrm{H}$ atau 6 Juni 2000 M di Surabaya dan kemudian mendapatkan badan Hukum Koperasi dari Kanwil Dinas Koperasi PK dan M Propinsi Jawa Timur dengan SK Nomor: 09/BH/KWK.13/VII/2000 tertanggal 22 Juli 2000.

BMT UGT Sidogiri didirikan oleh beberapa orang yang berada dalam suatu kegiatan urusan guru tugas pondok pesantren Sidogiri (Utusan GT PPS) yang di dalamnya terdapat orang-orang yang berprofesi sebagai guru dan 
pimpinan madrasah, alumni pondok pesantren Sidogiri Pasuruan dan para simpatisan yang menyebar di wilayah Jawa Timur.

Dalam setiap tahun BMT UGT Sidogiri membuka beberapa unit pelayanan anggota di kabupaten/kota yang dinilai potensial. Pada saat ini BMT UGT Sidogiri telah berusia 18 tahun dan sudah memiliki 440 unit layanan baitul mal wat tamwil/jasa keungan syariah dan 1 unit pelayanan transfer.

Pengurus selalu berusaha melakukan perbaikan dan pengembangan secara berkesinambungan pada semua bidang baik organisasi maupun usaha. Untuk menunjang hal tersebut maka anggota koperasi dan penerima amanat perlu memiliki karakter STAF, yaitu shiddiq (jujur), tabligh (Transparan), amanah (dapat dipercaya) dan fathanah (profesional).

Manajemen yang digunakan adalah manajemen Rasul, yakni shiddiq/jujur, amanah/dapat dipercaya, dan fathanah/profesional. Dalam penerapan sistem manajemennya BMT Sidogiri menerapkan sistem jemput bola, jadi setiap Account officer setiap hari mendatangi anggota BMT Sidogiri yang hendak melakukan transaksi dan BMT Sidogiri juga memiliki sebuah alat yang digunakan untuk transaksi penyetoran atau penarikan dana yang bekerjasama dengan MegaCom yang mana alat tersebut digunakan oleh Account Officer untuk mencatat transaksi, dan data transaksi tersebut akan secara otomatis masuk ke dalam komputer teller sehingga akan mempermudah nasabah untuk melakukan transaksi dan Accoun Officer juga tidak perlu mendata kembali anggota yang melakukan transaksi.

Dengan berkembangnya BMT UGT Sidogiri di dunia lembaga keuangan syariah, BMT Sidogiri terus melebarkan sayapnya yaitu dengan membuka kantor cabang di kabupaten Sidoarjo, yaitu di Jl. Soegiono 59B Panjunan Kepuh Kiriman Kec. Waru Kab. Sidoarjo.

Berkaitan dengan visi dan misi, visi BMT UGT Sidogiri adalah:

1. Terbangunnya dan perkembangnya ekonomi umat dengan landasan syariah Islam. 
2. Terwujudnya budaya ta'awun dalam kebaikan dan ketakwaan di bidang sosial ekonomi. Adapun misi BMT UGT Sidogiri adalah:

1. Menerapkan dan memasyarakatkan syariah Islam dalam aktivitas ekonomi.

2. Menanamkan pemahaman bahwa sistem syariah di bidang ekonomi adalah adil, mudah, dan maslahah.

3. Meningkatkan kesejahteraan umat dan anggota.

4. Melakukan aktivitas ekonomi dengan budaya STAF (Shiddiq/Jujur, Tabligh/Komunikatif, Amanah/Dipercaya, Fathanah/Profesional).

\section{Produk-produk BMT UGT Sidogiri Waru}

1. Produk Simpanan

Pada produk simpanan ini terdapat 8 produk yaitu antara lain:

a. Tabungan umum syariah: tabungan diakad berdasarkan prinsip syariah mudharabah musyarakah. Dengan nisbah 30\% anggota: 70\% BMT, dengan setoran awal minimal Rp. 10.000,- kemudian setoran berikutnya Rp. 1.000,- dan administrasi pembukaan tabungan Rp. 5.000,-.

b. Tabungan haji: tabungan diakad berdasarkan prinsip syariah mudharabah musyarakah dengan nisbah 50\%: $50 \%$, pembukaan rekening di kantor BMT UGT Sidogiri sesuai domisili calon jamaah haji, setoran awal minimal Rp. 500.000,- dan selanjutnya minimal Rp. 100.000,- dan penarikan hanya untuk kebutuhan keberangkatan haji.

c. Tabungan umrah: tabungan diakad berdasarkan prinsip syariah mudharabah musyarakah dengan nisbah 40\% anggota: 60\% BMT, dengan setoran awal minimal Rp. 100.000,- setoran berikutnya sesuai perencanaan keberangkatan, ketentuan keberangkatan sesuai dengan jadwal dari travel umrah, dana dapat dicairkan hanya untuk keperluan keberangkatan ibadah umrah kecuali udzur syar'i, dan administrasi pembukaan tabungan Rp. 150.000,. 
d. Tabungan idul fitri: tabungan untuk membantu anggota memenuhi kebutuhan hari raya idul fitri, tabungan diakad berdasarkan prinsip syariah mudharabah musyarakah dengan nisbah $40 \%$ anggota: $60 \%$ BMT. Setoran awal Rp. 100.000,- setoran berikutnya Rp. 1.000,- biaya adiministrasi Rp. 5.000,- dan penarikan tabungan dapat dilakukan paling awal 15 hari sebelum hari raya idul fitri.

e. Tabungan qurban: tabungan diakad berdasarkan prinsip syariah mudharabah musyarakah dengan nisbah 40\% anggota: 60\% BMT. Setoran awal minimal Rp. 50.000,kemudian setoran berikutnya Rp. 25.000,- saldo setelah pelaksanaan aqiqah dan qurban minimal Rp. 50.000,- dan hanya dapat diambil untuk keperluan aqiqah dan qurban, perencanaan ibadah qurban 5 bulan sampai dengan 24 bulan.

f. Tabungan lembaga peduli siswa: tabungan diakad berdasarkan prinsip syariah mudharabah musyarakah dengan nisbah 40\% anggota: $60 \%$ BMT. Setoran awal Rp. 100.000,- dan setoran berikutnya minimal Rp. 50.000 ,- dan penarikan tabungan siswa hanya boleh dilakukan di akhir tahun pelajaran.

g. Tabungan mudharabah berjangka: tabungan di akad berdasarkan prinsip syariah mudharabah musyarakah dengan nisbah sebagai berikut:

1) Jangka waktu 1 bulan nisbah 50\% anggota: 50\% BMT.

2) Jangka waktu 3 bulan nisbah 52\% anggota: $48 \%$ BMT.

3) Jangka waktu 6 bulan nisbah 55\% anggota: $45 \%$ BMT.

4) Jangka waktu 9 bulan nisbah 57\% anggota: 43\% BMT.

5) Jangka waktu 12 bulan nisbah 60\% anggota: 40\% BMT.

6) Jangka waktu 24 bulan nisbah 70\% anggota: 30\% BMT. 
Dengan setoran minimal Rp. 500.000,- dan jangka waktu fleksibel.

h. Tabungan mudharabah berjangka plus: tabungan diakad berdasarkan prinsip syariah mudharabah musyarakah dengan nisbah 45\% anggota: 55\% BMT. Jangka waktu tabungan 36 bulan, nominal tabungan mulai dari $\mathrm{Rp} 25$ juta dan berlaku kelipatan sampai dengan $\mathrm{Rp}$ 100 jt, tidak boleh ditarik sebelumnya berakhirnya masa kontrak kecuali ada udzur syar'i. ${ }^{17}$

2. Produk Pembiayaan

Pada produk pembiayaan terdapat 5 produk yaitu antara lain:

a. UGT MUB (Modah Usaha Barokah): akad yang digunakan mudharabah/musyarakah atau murabahah, jangka waktu pembiayaan maksimal 36 bulan, maksimum pembiayaan sampai dengan $\mathrm{Rp} 500$ juta.

b. UGT MTA (Multiguna Tanpa Agunan): akad yang digunakan murabahah atau ijarah, kafalah, dan hiwalah atau qordul hasan. Jangka waktu pembiayaan maksimal 1 tahun, maksimum plafon pembiayaan sampai dengan Rp. 1.000.000,-.

c. UGT KBB (Kendaraan Bermotor Barokah): akad yang digunakan murabahah, jangka waktu pembiayaan maksimal 5 tahun sedangkan kendaraan bekas maksimal 3 tahun, usia pemohon pada saat pengajuan minimal 18 tahun dan maksumal 55 tahun, dengan maksimum plafon pembiayaan sampai dengan Rp 100 juta untuk kendaraan bekas dan Rp 200jt untuk kendaraan baru.

d. UGT PBE (Pembelian Barang Elektronik): akad yang digunakan murabahah atau ijarah muntahiah bi altamlik, jangka waktu maksimal sesuai dengan jangka waktu garansi, DP atau uang muka 25\% dari ketentuan harga, dan maksimum plafon pembiayaan sampai dengan Rp 10 juta. 
e. UGT PKH (Pembiayaan Kafalah Haji): akad yang digunakan kafalah bil ujrah, membayaran biaya legalisasi surat kuasa pembatalan porsi di notaris (biaya tergantung masing-masing notaris), maksimal dana kafalah sebesar $90 \%$ dari biaya setoran awal BPIH untuk medapatkan nomor seat porsi haji, pembayaran dengan sistem angsuran. ${ }^{18}$

\section{Mekanisme dan Syarat Mudharabah}

Mekanisme akad Mudharabah di BMT Sidogiri adalah:

1. Mudharib dan Shahibul Mal melaksanakan kerjasama usaha. Bagi hasil ditetapkan sesuai dengan presentase nisbah yang telah diperjanjikan antara Mudharib dan Shahibul Mal.

2. Shahibul Mal menyerahkan modal $100 \%$ artinya semua usaha akan dibiayai oleh modal milik Shahibul Mal.

3. Mudharib sebagai pengusaha atas dasar keahliannya, akan mengelola dana investasinya dalam sebuah proyek atau dalam sebuag usaha riil.

4. Pendapatan atas hasil usaha proyek tersebut akan dibagi sesuai dengan nisbah yang telah diperjanjikan.

5. Pada saat jatuh tempo perjanjian, maka modal yang telah diinvestasikan oleh Shahibul Mal akan dikembalikan semuanya (100\%) oleh Muharib kepada Shahibul Mal dan akad mudharabah akan berakhir.

Dalam pembiayaan mudharabah I BMT UGT Sidogiri Waru membantu dalam hal modal bagi anggota BMT UGT yang ingin mengembangkan usahanya. Anggota yang ingin melakukan pembiayaan mudharabah, mengisi data terlebih dahulu ke BMT UGT Sidogiri Waru.

Adapun syarat-syarat pengajuan akad mudharabah di BMT UGT Sidogiri Waru:

1. Anggota harus mempunyai simpanan sebesar Rp 60.000, karena koperasi untuk melakukan simpanan harus dari anggota terlebih dahulu

${ }^{18}$ BMT Sidogiri, Produk Pembiayaan Koperasi BMT UGT Sidogiri (Pasuruan: Kantor Pusat BMT Sidogiri, n.d.). 
2. Koperasi mempunyai hukum tertentu sesuai UndangUndang Koperasi harus menjadi anggota koperasi baru pihak koperasi bisa menghimpun dana anggota.

3. Identitas diri

4. Melakukan simpanan Rp 60.000

5. Nisbahnya $30 \%$ keuntungan untuk anggota dan $70 \%$ keuntungan untuk koperasi.

\section{Analisis Perspektif Hukum Islam terhadap Mudharabah di BMT Sidogiri}

Fatwa DSN Nomor 07/DSN-MUI/IV/2000 Tentang Pembiayaan Mudharabah Ketentuan Pembiayaan:

1. Pembiayaan Mudharabah adalah pembiayaan yang disalurkan oleh LKS kepada pihak lain untuk suatu usaha yang produktif.

2. Jangka waktu usaha tata cara pengembalian dana, dan pembagian keuntungan ditentukan berdasarkan kesepakatan kedua belah pihak.

3. Mudharib boleh melakukan berbagai macam usaha yang telah disepakati bersama dan sesuai dengan syariah dan LKS tidak ikut serta dalam managemen perusahaan.

4. Jumlah dana pembiayaan harus dinyatakan dengan jelas dalam bentuk tunai dan bukan piutang.

5. Biaya operasional dibebankan kepada mudharib.

6. Dalam hal ini penyandang dana (LKS) tidak melakukan kewajiban atau melakukan pelanggaran terhadap kesepakatan, mudharib berhak mendapat ganti rugi atau biaya yang telah dikeluarkan.

Dari segi rukun dan syarat pembiayaan:

1. Penyedia dana (shahibul $\mathrm{mal}$ ) dan pengelola (mudharib) harus cakap hukum.

2. Penyataan ijab dan qabul harus dinyatakan oleh para pihak untuk menunjukkan kehendak mereka dalam mengadakan kontrak (akad)

3. Modal ialah sejumlah uang dan atau aset yang diberikan oleh penyedia dana kepada mudharib untuk tujuan usaha. 
4. Keuntungan Mudharabah adalah jumlah yang didapat sebagai kelebihan dari modal.

5. Kegiatan usaha oleh pengelola (mudharib), sebagai perimbangan (muqabil) modal yang disediakan oleh penyedia dana.

Terdapat Ketentuan lain diantaranya adalah:

1. Mudharabah boleh dibatasi pada periode tertentu.

2. Kontrak tidak boleh dikaitkan dengan sebuah kejadian dimasa depan yang belum tentu terjadi.

3. Pada dasarnya mudharabah tidak ada ganti rugi, karena pada dasarnya akad ini bersifat amanah, kecuali akibat dari kesalahan disengaja, kelalaian, atau pelanggaran kesepakatan.

4. Jika salah satu pihak tidak menenuaikan kewajibanya atau jika terjadi perselisihan di antara kedua belah pihak, maka penyelesaiannya dilakukan melalui Badan Arbitrase.

Berdasarkan data di lapangan diketahui bahwa BMT Sidogiri menerapkan akad mudharabh pada produk simpanan yang meliputi 8 produk yaitu:

1. Tabungan umum syariah: tabungan diakad berdasarkan prinsip syariah mudharabah musyarakah. Dengan nisbah 30\% anggota: $70 \%$ BMT.

2. Tabungan haji: tabungan diakad berdasarkan prinsip syariah mudharabah musyarakah dengan nisbah 50\%: $50 \%$.

3. Tabungan umrah: tabungan diakad berdasarkan prinsip syariah mudharabah musyarakah dengan nisbah 40\% anggota: $60 \%$ BMT.

4. Tabungan idul fitri: tabungan untuk membantu anggota memenuhi kebutuhan hari raya idul fitri, tabungan diakad berdasarkan prinsip syariah mudharabah musyarakah dengan nisbah 40\% anggota: 60\% BMT.

5. Tabungan qurban: tabungan diakad berdasarkan prinsip syariah mudharabah musyarakah dengan nisbah 40\% anggota: $60 \%$ BMT. 
6. Tabungan lembaga peduli siswa: tabungan diakad berdasarkan prinsip syariah mudharabah musyarakah dengan nisbah 40\% anggota: $60 \%$ BMT.

7. Tabungan mudharabah berjangka: tabungan di akad berdasarkan prinsip syariah mudharabah musyarakah dengan nisbah sebagai berikut:
a. Jangka waktu 1 bulan nisbah 50\% anggota: 50\% BMT.
b. Jangka waktu 3 bulan nisbah 52\% anggota: 48\% BMT.
c. Jangka waktu 6 bulan nisbah 55\% anggota: 45\% BMT.
d. Jangka waktu 9 bulan nisbah 57\% anggota: 43\% BMT.
e. Jangka waktu 12 bulan nisbah 60\% anggota: 40\% BMT.
f. Jangka waktu 24 bulan nisbah 70\% anggota: 30\% BMT.

8. Tabungan mudharabah berjangka plus: tabungan diakad berdasarkan prinsip syariah mudharabah musyarakah dengan nisbah $45 \%$ anggota: $55 \%$ BMT. ${ }^{19}$

Setiap produk tersebut memiliki ketentuan dan persyaratan khusus sesuai kebutuhan yang telah ditetapkan.

Berdasarkan rukun dan syarat muharabah yang ditentukan fatwa DSN MUI, diketahui bahwa mudharabah yang ditawarkan di BMT Sidogiri sudah memenuhi syarat tersebut, sebagaimana berikut ini:

1. Penyedia dana (shahibul mal) dan pengelola (mudharib) harus cakap hukum.

Shahibul mal adalah nasabah BMT Sidogidi dan BMT Sidogiri sebagai mudharib.

2. Pernyataan ijab dan qabul harus dinyatakan oleh para pihak untuk menunjukkan kehendak mereka dalam mengadakan kontrak (akad).

Ijab qabul antara shahibul mal (nasabah) dan mudharib (BMT Sidogiri) tertuang dalam formulir.

3. Modal ialah sejumlah uang dan atau aset yang diberikan oleh penyedia dana kepada mudharib untuk tujuan usaha ditawarkan.

\footnotetext{
${ }^{19}$ BMT Sidogiri, Produk Simpanan (Pasuruan: Kantor Pusat BMT Sidogiri, n.d.).
} 
Dalam setiap produk mudharabah yang ditawarkan di BMT Sidogiri, masing-masing produk mewajibkan shahibul mal menyertakan setoran awal dengan nilai tertentu yang dijadikan sebagai modal.

4. Keuntungan Mudharabah adalah jumlah yang didapat sebagai kelebihan dari modal.

Keuntungan tersebut dijelaskan melalui prosentasi bagi hasil antara shahibul mal dan mudharib.

5. Kegiatan usaha oleh pengelola (mudharib), sebagai perimbangan (muqabil) modal yang disediakan oleh penyedia dana.

Dalam hal ini BMT Sidogiri sebagai mudharib mempunyai hak mengelola dana nasabah.

\section{Penutup}

Koperasi BMT Usaha Gabungan Terpadu Sidogiri disingkat "Koperasi BMT UGT Sidogiri" mulai beroperasi pada tanggal 5 Rabiul Awal $1421 \mathrm{H}$ atau 6 Juni 2000 M. di Surabaya dan kemudian mendapatkan badan Hukum Koperasi dari Kanwil Dinas Koperasi PK dan M Propinsi Jawa Timur dengan SK Nomor: 09/BH/KWK.13/VII/2000 tertanggal 22 Juli 2000.

Produk di BMT UGT Sidogiri Waru ada dua yaitu: produk pembiayaan dan produk simpanan. Produk pembiayan terdiri dari gadai emas syariah, modal usaha barokah, multiguna tanpa agunan, kendaraan motor barokah, pembelian barang elektronik, dan pembiayaan kafalah haji. Sedangkan produk simpanan terdiri dari tabungan umum syariah, tabungan haji al-haromain, tabungan umrah al-hasanah, tabungan idul fitri, tabungan qurban, tabungan lembaga peduli siswa, tabungan mudharabah berjangka, dan tabungan mudharabah berjangka plus. Akad mudharabah digunakan pada produk simpanan.

Fatwa DSN Nomor 07/DSN-MUI/IV/2000 Tentang Pembiayaan Mudharabah Ketentuan Pembiayaan: Pembiayaan Mudharabah adalah pembiayaan yang disalurkan oleh LKS kepada pihak lain untuk suatu usaha yang produktif, Jangka waktu usaha tata cara pengembalian dana, dan pembagian keuntungsn ditentikan berdasarkan kesepakatan kedua belah 
pihak, Mudharib boleh melakukan berbagai macam usaha yang telah disepakati bersama dan sesuai dengan syariah dan LKS tidak ikut serta dalam managemen perusahaan, Jumlah dana pembiayaan harus dinyatakan dengan jelas dalam bentuk tunai dan bukan piutang.

Menurut Fatwa Dewan Syariah Nasional (DSN-MUI) Mudharabah merupakan kerjasama antara pihak pertama (shahibul mal) dengan pihak kedua (mudharib), dimana dana $100 \%$ dari pihak shahibul maldan keuntungan usaha mudharabah dibagi menurut akad perjanjian, sedangkan apabila rugi ditanggung oleh pemilik modal selama kerugian itu tidak disebabkan oleh kelalaian si pengelola.

Berdasarkan praktik akad mudharabah di BMT Sidogiri disimpulkan bahwa praktik tersebut telah sesuai dengan fatwa DSN MUI, karena telah memenuhi rukun dan syarat mudharabah.

\section{Daftar Pustaka}

Antonio, Muhammad Syafii. Bank Syariah: Dari Teori Ke Praktik. Jakarta: Gemma Insani, 2001.

Atabik, Ahmad. "Analisis Historis Perkembangan." Iqtishadia 6, no. 2 (2013): 357-78.

Bakri, Adzan Noor, and Umi Masruroh. "Penerapan Nilai-Nilai Islam Dalam Bank Berbasis Syariah Dan Pengaruh Terhadap Loyalitas Nasabah." DINAMIS - Journal of Islamic Management And Bussines 1, no. 1 (2018): 33-45.

Bawenti, Karlina Aprilianingrum, and Faradila Hasan.

"Mudharabah Bank Syariah Ditinjau Dari Undang-Undang Nomor 21 Tahun 2008 Tentang Perbankan Syariah." Jurnal Ilmiah Al-Syir'ah 16, no. 1 (2018): 35-57. https://doi.org/10.30984/jis.v16i1.646.

BMT Sidogiri. Produk Pembiayaan Koperasi BMT UGT Sidogiri.

Pasuruan: Kantor Pusat BMT Sidogiri, n.d.

-_- Produk Simpanan. Pasuruan: Kantor Pusat BMT Sidogiri, n.d.

Firdaweri. "Perikatan Syariah Berbasis Mudharabah (Teori Dan Praktik).” ASAS 6, no. 2 (2014): 54-77. 
Ismail. Perbankan Syariah. Jakarta: Kencana, 2011.

Karim, Adiwarman. Bank Islam: Analisis Fiqih Dan Keuangan. Jakarta: PT Raja Grafindo Persada, 2004.

Kolistiawan, Budi. "Tantangan Lembaga Keuangan Syariah Dalam Menghadapi Masyarakat Ekonomi ASEAN." MUQTASID Jurnal Ekonomi Dan Perbankan Syariah 8, no. 1 (2017): 54-64.

https://doi.org/10.18326/muqtasid.v8i1.78-94.

Marimin, Agus, and Abdul Haris Romdhoni. "Perkembangan

Bank Syariah Di Indonesia." Jurnal Ilmiah Ekonomi Islam 1, no. 02 (2017): 75-87.

https://doi.org/10.29040/jiei.v1i02.30.

Masyithoh, Novita Dewi. "Analisis Normatif Undang-Undang

No. 1 Tahun 2013 Tentang Lembaga Keuangan Mikro (Lkm) Atas Status Badan Hukum Dan Pengawasan Baitul Maal Wat Tamwil (Bmt)." Economica: Jurnal Ekonomi Islam 5, no. 2 (2014): 17-36. https://doi.org/10.21580/economica.2014.5.2.768.

MUI, DSN. “FATWA DEWAN SYARI'AH NASIONAL NO: 07/DSNMUI/IV/2000 Tentang PEMBIAYAAN MUDHARABAH (QIRADH)." Jakarta, 2000.

Musadad, Ahmad. "Perniagaan Dalam Al-Qur'an (Studi

Perbandingan Tafsir Ahkamul Quran Karya Ibnu Al-Arabi Dan Tafsir Ahkamul Quran Karya Al-Kiya Al-Harasi)." EtTijarie 3, no. 2 (2016): 51-73.

Sa'diyah, Mahmudatus, and Meuthiya Athifa Arifin.

"Mudharabah Dalam Fiqih Dan Perbankan Syari'Ah."

Equilibrium : Jurnal Ekonomi Syariah 1, no. Desember (2013): 302-23.

Suhendi, Hendi. Fiqh Muamalah. Jakarta: PT Raja Grafindo Persada, 2013.

Yazid, Muhammad. Fiqh Muamalah Ekonomi Islam. Surabaya: Imtiyaz, 2017. 